\title{
Critical Literacy for ELT in Indonesia: What EFL Teachers should be Aware of
}

\author{
Anitha Thalib Mbau \\ Yogyakarta State University, Indonesia \\ sayaanithathalib@gmail.com \\ Bambang Sugeng \\ Yogyakarta State University, Indonesia \\ ba_geng@yahoo.com
}

\begin{abstract}
This article explores the basic and important issues related to critical literacy for ELT in Indonesia. Hopefully, it could contribute to improving EFL teachers' understanding of critical literacy, particularly in Indonesia. Critical literacy is still considered as a new approach in EFL contexts. However, it is promising such benefits for both students and teachers for it might contribute to developing both teachers' and students' critical manners in reading and writing. This article describes the concept of critical literacy. Then, it elaborates the appropriate learning sources and activities to support the development of students' critical literacy. After that, it describes some challenges for implementing critical literacy in ELT in the Indonesian context briefly. Finally, it offers conclusions on the important points of the topic.
\end{abstract}

Keywords: critical literacy, ELT, learning sources, learning activities

\section{INTRODUCTION}

Critical literacy is becoming a popular issue to be investigated in both Englishspeaking countries and non-English speaking countries, particularly in ELT, ESL, or EFL contexts. For the last four decades, critical literacy has been studied widely in speaking English countries such as Australia, Canada, New Zealand, the United Kingdom, and the United States of America in various school contexts including vocational and adult education 


\section{Anitha Thalib Mbau \& Bambang Sugeng}

(Fajardo, 2015). At the same time, the discussions and studies about the shift from simply decoding texts to understanding how meaning systems and power work on people with the critical approach are increasing (Kuo, 2014). However, in EFL settings critical literacy has not gained popularity as it has in the English-speaking country; yet it displays its development as one important issue to discuss for the sake of students' development both in term of their English language proficiency and their ways of thinking.

Some researchers and language practitioners have noted some reasons why critical literacy is still considered as a marginalized issue in ESL/EFL contexts. There are at least four reasons that explain this condition. Firstly, as Crookes \& Lehner (1998) argued, ESL/EFL teachers mostly perceive themselves as persons who just simply help people for being able to communicate. As the consequence, their teaching tends to be less engaged in critical literacy which includes about socio-political issues. Secondly, Benesch (1993) and Pennycook (1997) stated that the persistence towards pragmatic ideology and neutrality contribute to the de-emphasis of critical literacy. It is because pragmatism and neutrality which are manifested in resources and learning activities only lead students to think superficial matters rather than more complex issues. Thirdly, according to Kim (2012), teachers have a lack of understanding of the urgency of critical literacy. Lastly, Kim (2012) also noticed that even though teachers are trying to adopt critical literacy into their programs, they still have insufficient knowledge and skills about how to implement it in non-Western contexts.

Even though critical literacy is considered as a new alternative approach in language teaching particularly in EFL context (Gustine, 2018), yet it is very needed. For instance, a phenomenon happens in Indonesia where information published or released in mass media or even social media is often perceived as the truth by some people with no further efforts to do investigation or to compare "the truth" from different perspectives (Gustine, 2018), it reflects the urgency of critical literacy for Indonesian students. In addition, Freebody (2007) claimed that students' literacy levels are in decline or at least insufficient for contemporary society. Then, learning a language which will enable them to be fluent and accurate in using the language is not enough. Thus, they also have to be able to select, interpret, and reflect the information they get, further, to produce the information.

To do so, critical literacy will help them to develop their ability to critically assess and investigate the hidden motives and under the surface ideas of all types of texts: visual, print, digital, and audio (Ciardiello, 2004). In other words, students will be engaged in higher levels of reading and discussion as well as conveying their own life experience, giving those chances for participation and understanding the power of language (Soares \& Wood, 2010). Therefore, they will not be manipulated by the texts they read (Freire as cited in McLaughlin $\&$ DeVoogd, 2004). Since students need to know not only to decode texts but also to understand how power and system of meaning work on people by critical approach (Kuo, 2014), then, teachers should be able to facilitate them and perceive it as their students' needs which should not be neglected.

The fact that EFL teachers in ESL/EFL contexts such as in Indonesia still have a lack of understanding and skills about critical literacy must not be neglected. Gustine (2018) found that even though teachers have had about seven years of experiences in teaching 
English in different levels of schools, some teachers still display an absence of knowledge on critical literacy as a practical approach to English teaching. This will lead teachers to what Shor (1999, p. 14) called it as "not having enough authority" which refers to lack of capability of the teachers to initiate a critical and power-sharing process. It means that teachers still need help to increase or develop their critical literacy knowledge and practice in the classroom. Therefore, more resources on a critical literacy concept and practical issues are needed. The present article is intended to fulfill this gap. This article will first elaborate the concept of critical literacy; secondly, examine the resources needed in term of texts; thirdly, discuss the various types of activities to support students' critical literacy; and lastly, make a conclusion of the important points of the topic.

\section{CRITICAL LITERACY}

The notion of critical literacy is rooted in the work of Paulo Freire, Pedagogy of the Oppressed (Anderson \& Irvine, 1993). Freire insisted that if teachers help students from oppressed communities to read the words but do not at the same time teach them to read the world, students might become literate in a technical sense but will remain passive objects of history rather than active subjects. According to Freire, "subjects" are those who know and act; "objects" are those who are known and acted upon. Thus, critical literacy theory is derived from the theory of critical theory. Critical theory is quite similar to the social theory which emphasizes evaluation and critiques of social and political issues in a certain society. This view then influences critical literacy concepts especially in terms of examining the power within texts through language (Yoon, 2015).

Therefore, critical literacy is strongly related to the issues of sociology and politics scrutinizing the connection between language and power within texts (Yoon, 2015). Since it is close to texts, critical literacy also deals with reading and writing activities. As Anderson \& Irvine (1993) argue, critical literacy is to learn how to read and write as a process to become aware of experiences which are historically constructed in a specific connection of particular power. In other words, it focuses more on acknowledging whose voice is heard or silenced and how the structure of the language represents power (Yoon, 2015). Its purposes are to encounter these imbalanced power relations (Anderson \& Irvine, 1993); to comprehend the authority of language (Janks, 2000; Soares \& Wood, 2010) and to analyze, critic, and transform the norms, rule systems, and social practices in institutions and in everyday life (Luke, 2004).

Literacy can be seen as a technique, set of skills of language, set of cognitive capabilities, and a group of social performances and it is perceived as a phenomenon of dynamic cultural processes rather than static mental traits (Kern, 2003). Literacy, therefore, not only about breaking codes of texts but also about creating and interpreting meaning through texts. The term "critical" is closely related to the spirit of reflective skepticism (Kern, 2003). In the present article, writers view critical literacy as a set of skills as well as techniques to deal with texts which cover reading and writing activities.

Additionally, critical literacy includes subsequent predicting; reading by scrutinizing; questioning hard and harder questions sighted beneath, behind, and beyond texts; and attempting to uncover how texts are constructed and how power takes advantage over us, others, under whose name, for whose advantage (Luke, 2004). Thus, transforming the 


\section{Anitha Thalib Mbau \& Bambang Sugeng}

concepts of critical literacy into the classroom will aid students and teachers to enlarge their thoughts, find out multiple perspectives, and grow into active thinkers (McLaughlin \& DeVoogd, 2004) especially to understand and manage the connections between language and power (Janks, 2000). In other words, critical literacy enables students to carry their personal experiences into discussions, giving them chances to participate and involving them into higher reading levels and discussions, and to comprehend the authority of language (Soares \& Wood, 2010). Those skills are needed by students to interact wisely with an immense of information that they can easily access this information or digital era.

To put the concept of critical literacy into practice, Lewison, Flint, \& Van Sluys (2002) proposed four dimensions of critical literacy which help teachers to organize what their students should go through in the teaching and learning process. Furthermore, the dimensions are the results of synthesizing existed literatures of critical literacy theories in last 30 years. Those dimensions are: (a) disrupting the commonplace, (b) interrogating multiple viewpoints, (c) focusing on sociopolitical issues, and (d) taking action and promoting social justice. For more detail explanation, these are elaborated as below.

\subsection{Disrupting the commonplace}

Disrupting the commonplace means that critical literacy is understood as perceiving routines into a new point of views (Lewison et al., 2002). It means that language and any other sign systems are used to identify perception modes particularly the implicit one and to think through novel borders to comprehend experiences. Through this dimension, critical literacy is the way to problematize every field of study, to understand that our existing knowledge as the product of history, to interrogate texts, to embrace popular culture and media as a part of everyday life and to analyze how people are constructed by media, to develop the language of critique, to analyze how language shapes identity, constructs discourses of culture, disrupts or supports the status quo (Alan Luke, 2000; Allan Luke \& Freebody, 1997; Shor, 1987; Vasquez, 2000).

Therefore, in this stage students will be invited to problematize and interrogate texts by asking questions such as "How is this text trying to position me?" and by examining how text profile identity, create cultural discourse, and support or interrupts the existing state of affairs (Gee, 2008; Vasquez, 2000). In other words, students should develop their skills in problematizing and interrogating texts which are usually perceived as it is.

\subsection{Interrogating multiple viewpoints}

This means that students are asked to see experiences and texts from their own perspectives and others' (Lewison et al., 2002). They are also asked to simultaneously consider those various perspectives. Thus, students should have skills on reflecting on multiple and opposing perspectives, using those voices to question texts, finding out marginalized voice and making differences noticeable.

Through this dimension, students will be engaged in the activities which can open their mind and heart towards theirs and others' perspectives. Thus, this dimension focuses on the questions like "whose voices are missing and whose are heard?"(Harste et al., 2000; Allan Luke \& Freebody, 1997). Teachers will help students reflect and interrogate texts through 
multiple perspectives, focus on the marginalized voices, examine the dominant voices, and create the visibility of making differences. In this case, there will be no tidy conclusion towards any texts as what usually happens as the heritage of conventional schools.

\subsection{Focusing on sociopolitical issues}

This dimension means that teaching and the use of language are perceived to be never neutral or always influenced by sociopolitical systems and power connections (Lewison et al., 2002). Consequently, in this case, students are expected to have the skills to understand the sociopolitical systems and challenging unequal power relationships.

Within this dimension, students are invited to go beyond their personal life, to go further towards sociopolitical systems where we live, to challenge the status quo by analyzing the connection between power and language, and to be literate when they are engaged in political issues they found in their daily life (Comber, 2001; Lankshear, McLaren, \& McLaren, 1993). Through this dimension, students will step out and see how actions, responses, and perception are shaped by sociopolitical systems and power.

\subsection{Taking action and promoting social justice}

This dimension is actually the expansion of the understanding and perspectives from the previous three dimensions above. In order to take an action and promoting social justice, students should have skills on reflecting and acting towards the world as a means of transformation, questioning practices and injustice, analyzing how language is used to sustain authority, and redefining cultural borders (Lewison et al., 2002).

In this part, students will do more complex stuff. They will get engaged in reflecting and acting towards their environment as a means for transformation, using the language to examine power in order to enhance their life and to question injustice, examining how language is used to sustain the domination and how the opposite groups get access towards the dominant groups without devaluating their culture, and how the prevailing discourses can be changed by the social actions, and redefining and challenging students to cross the borders of cultures to create borders using diverse of cultural sources (Comber, 2001; Freire, 1972; Giroux, 1993; Janks, 2000). This dimension would be the last one and it is also usually perceived that critical literacy cannot be separated by social actions.

\section{LEARNING RESOURCES FOR CRITICAL LITERACY}

Selecting the appropriate learning sources for students is not an easy task for some teachers. In as much as critical literacy aims at engaging students in more complex activities, the learning source should support them in such activities. Therefore, students should be given texts which could engage them to do critical analyses. It is because critical literacy is generally related to critical text analyses (Luke, 2013). Therefore, selecting the appropriate texts is one of the main tasks of teachers. Being appropriate here refers to the capability of the texts to give space for students to do subsequent predicting; reading by scrutinizing the connection between language and power within texts; questioning hard and harder questions sighted beneath, behind, and beyond texts; and attempting to uncover how texts are constructed and how power takes advantage over us, others, under whose name, and for whose advantage (Alan Luke, 2004; Yoon, 2015). Since language has the main role to do 


\section{Anitha Thalib Mbau \& Bambang Sugeng}

construction and reconstruction of social and historical, the texts provided should also contain cultural and ideological assumptions that underwrite texts, the representation of politics, and the discriminatory cultural positioning of speakers and readers within discourses (Morgan, 2002). Thus, students will not only do breaking codes of the texts but also creating and interpreting meaning through texts (Kern, 2003). Furthermore, they are encouraged to use these codes as tools in reflecting and constructing meanings from texts and discourses (Beck, 2005) while writing (Gainer, 2013).

In the Indonesian context, EFL teachers usually rely on the books provided by the Education Ministry or any commercial books approved by the Education Ministry. However, there is an important thing to acknowledge that Ministry of Education and Culture (2016) about the books used by the education unit should not contain any pornography, extremism, radicalism, violence, SARA, bias gender, and any inappropriate values. It means that the textbooks provided by the Ministry tend to be neutral. If it is so, then, the manifestation of neutrality in the textbooks will not lead students to see the complexity of issues as a factor, as Pennycook (1997) had considered de-emphasizing on critical literacy. Yet, it does not mean that teachers cannot use these textbooks. Teachers still can use them for engaging students to the first dimension of critical literacy which is disrupting the commonplace. At this point, students would like to question and problematize what is perceived as something normal in everyday life.

Furthermore, to engage students in the other three dimensions, the most appropriate texts should be the ones containing controversial issues. By being controversial, here, is meant that the issues should carry personal, social, and political impacts, provoke feelings, and cope with questions of beliefs or values (Oxfam, 2006). Texts containing controversial issues should be chosen by considering their relevance to students' everyday life. Thus, students will find the materials discussed are meaningful. Hopefully, it could increase their motivation for being engaged actively through the discussion of the chosen issues.

In addition, teachers should also acknowledge the recent empirical studies showing that the use of multi-modal texts is becoming the center of interpretation in critical literacy (Fajardo, 2015). It seems like the definition of texts in the 21 st century is expanded in order to accommodate the practice of multimodal literacy (Mills, 2010). Fajardo (2015), then, summarized those multimodal texts to include picture books, political cartoons, graphic novels, reality television shows, advertisement, ranges of digital texts, speeches, gestures, clothing, or popular cultures. The use of varied sources of learning materials is intended to involve students to do exploration from different perspectives.

\section{LEARNING ACTIVITIES FOR CRITICAL LITERACY}

The main characteristic of learning activities for critical literacy is critical and dialogical. It is because dialogical activities are simple but powerful in delivering the moral ideal of critical literacy and it would also include critique as a tool to reach understanding (Endres, 2001). This would give more space for both students and teachers to do critical reflection on the issues. Therefore, some scholars propose several critical questions (see Huang, 2011; Janks, 2012; Allan Luke \& Freebody, 1999; Rice, 1998) to guide the learning process. It is to guide and stimulate students to seek what they should focus on and also to 
give opportunities for them to offer their critical opinions. Thus, critical literacy seems to give more attention to critical reading and writing activities. It is because those types of activities "always involve perception and interpretation" (Freire \& Macedo, 1987, p. 24).

Some studies in EFL settings display positive results towards those kinds of activities. The activities mostly in form of discussion (Huang, 2011; Izadinia \& Abednia, 2010; Park, 2011; Shin \& Crookes, 2005) and writing critical responses towards the texts which have already read and discussed in form of reflective journals, response papers or essays (Huang, 2011; Izadinia \& Abednia, 2010; Park, 2011; Suarcaya \& Prasasti, 2017). In discussion sessions, the activities involve students and teachers to establish critical dialogue and also encompass students' personal perspectives.

Through such activities, students' critical awareness is developed. It is to say that critical literacy activities contribute to their critical awareness such as improvement of critical thinking ability (Izadinia \& Abednia, 2010), showing, revealing and developing a critical stance (Kuo, 2014; Shin \& Crookes, 2005; Suarcaya \& Prasasti, 2017), acknowledging multiple perspectives (Huang, 2011; Kuo, 2014), actively voicing their opinions and bringing meaning towards texts by deconstructing and/ deconstructing the texts (Park, 2011; Suarcaya \& Prasasti, 2017), uncovering hidden messages (Huang, 2011) and helping them re-examine their familiar world (Kuo, 2014). Critical literacy could also enhance students' speaking, writing (Izadinia \& Abednia, 2010) and reading comprehension (Huang, 2011). In other words, critical literacy through critical and dialogical activities could help students raising their awareness of multi-perspectives towards an issue, it would help them develop their ability to reflect, to evaluate, and to critique information they get.

Another important thing teachers should acknowledge the learning activities for critical literacy is about multiple perspectives. Students should be aware that "texts don't contain one fixed, definite meaning put there by the author. Different kinds of readers in different societies and times can produce different meanings for the same texts" (Morgan, 2002, pp. 41-42). Hence, the learning activities could be approached through various ways such as reading different versions of the same topic, reading a story that reveals varying points of view, discussing the perspectives of people with different cultural backgrounds, or identifying the dominant and silenced voices in a text, debates, rewriting texts from another perspective, role-plays, think-aloud, juxtaposing texts of varying viewpoints on the same topic, or raising critical questions (Fajardo, 2015, p. 32).

Fajardo (2015) further explained that acknowledging different perspectives does not mean that students should automatically change their stances or even deny others'. It is likely to raise students' awareness to see truths as partial and limited; thus, as Ciardiello (2004) noted, there would not be a representation of events in forms of texts which would be able to tell the entire story. This would make students aware that giving simple answers to a complex problem is not enough.

\section{CRITICAL LITERACY AND ELT IN INDONESIAN CONTEXT}

English language teaching in Indonesia has adopted the genre-based approach which is more familiar as the text-based approach. Therefore, the learning materials provide rages genres of texts such as descriptive, narrative, procedure, expository, news item, recount, and anecdote. Genre theories and its implementation in language learning and teaching mainly 


\section{Anitha Thalib Mbau \& Bambang Sugeng}

focus on two purposes, to comprehend the relationship between language and contexts and to employ this understanding towards language and literacy education (Hyland, 2002). This view language system encloses sets of options for speakers/writers based on their intention how meanings they want to make (Lock, 1996). Therefore, language is seen as the resource to make meanings and purposes in expressing two sorts of meaning called experiential meaning or the way language used to represent understandings of the world and interpersonal meaning or the way language create relationships with others (Halliday, 1994).

However, when structuralist view is adopted, the genre approach would become instrumentalist where text types as forms are seen unproblematically in a culture-free area (Derewianka, 2003). Consequently, the implementation of the genre approach would be implemented in a traditional sense where the focus is on transferring the knowledge of genre without giving more space for students to explore and to put their personal view. This condition does not see that the notions of genre recently stress that the nature of the genre is flexible and rhetorical rather than formulaic and static rules (Melrose, 1995).

Therefore, a genre-based approach is actually relevant to help students develop their critical literacy skills. Since genres are ideological in the sense that they would never be free of beliefs and values and their tendency that some genres become dominant and hegemonic in a community (Hyland, 2002), being critical is a must for students to sense the ideological aspects of texts they read. Since critical literacy would help students raising their awareness of multi-perspectives towards an issue, they would develop their ability to reflect, evaluate and critique information they get. In short, students will be helped to develop their critical reading ability.

Critical reading is a very important skill for everyone to have in this information era (Priyatni \& Nurhadi, 2017). Particularly for students who are educated, they should be able not only to understand but also to assess and reflect what they read, so they can be wise to every information they get. Ideally, students at the secondary level should be able to be engaged in a higher level of reading activities such as assessing and reflecting complex written texts (Ministry of Education and Culture, 2016b). In the end, students who are always engaged in critical reading would give positive contributions to themselves, society, and nation as social agents of change.

Unfortunately, Indonesian students' reading ability is still considered as low. Program for International Students Assessment (PISA) in 2015 reported that Indonesian was in 64th rank out of 72 (OECD, 2016). To be more specific on students' reading literacy, Indonesia also still at a low level as well, level 2 with mean score 402 . There are 6 levels to indicate the reading literacy level of the students. The minimum score for good reading literacy is 500 for senior high school students which is level 4 . The characteristics of level 4 are able to interpret, reflect, and critically evaluate complex texts. It means that Indonesia still has to work hard for increasing the students' reading literacy level. In level 2, students' ability is still at a low level of reading. They are only able to get the main idea of a passage, to understand the relationship, and to construct meaning for making inferences (Harsiati, 2018). Consequently, when they are asked to reveal information, to develop and integrate interpretation, and to reflect and evaluate complex texts, they will get difficulties. This condition is quite similar to students' English reading habit which do not indicate as a good 
reading habit even though they have learned English for more than 10 years at school (Iftanti, 2012). It reflects that students of Indonesia need to be helped to develop their critical reading literacy in both first and foreign language contexts.

Especially in foreign language contexts, schools have a very vital role to help students develop their critical reading skill. It is because, as a foreign language, students get lack exposure from outside of the classroom. It means that they rely much on their learning at schools. Furthermore, since reading cannot be separated from writing, then, developing students' critical reading skills also means developing students' writing skills. Indonesian government through the national education system (Republic of Indonesia, 2003) which states that the implementation of education should develop students' reading and writing culture at schools. It means that the Government also perceive reading and writing ability as important skills that students need for being able to give positive contributions towards themselves, community, society, and nation. Thus, the realization of the Government's commitment, they run a literacy movement to promote the importance of reading and writing at school. However, it is still going to be a long journey until arriving at the state of being critical readers and writers for Indonesian students. It is because the literacy movement is still in the initial stage which focuses on developing students' reading interest.

However, Indonesia should be optimistic that Indonesian students also can be critical readers and writers as long as they are well facilitated. Therefore, stakeholders should work together to achieve that goal. Teachers and texts are important elements (Fajardo, 2015; Shor, 1999) without denying others such as schools' environment. The teachers should be prepared and facilitated for being critical readers and writers as well. For it is impossible for them helping their students to be critical readers and writers if they could not read and write in a critical manner (Solihati \& Hikmat, 2018). The texts also should be designed or selected to facilitate students developing their critical literacy skills. Teachers, of course, could also use other sources such as newspapers, magazines, literary works, and so forth to support the learning process (Fajardo, 2015). Nevertheless, since textbooks published by the Government are the main sources of learning in the classroom (Ministry of Education and Culture, 2016a), the textbooks should be good enough to support students' critical literacy.

Regarding the issue of critical literacy in the Indonesian context as elaborated above, the authors identified some problems raised towards this issue. First, students' critical literacy levels are still low. Particularly for senior high school students, they should be able to interact with complex texts in critical manners. It means that they should be able to interpret, critique, and reflect the information they get from texts. However, in reality, they are only able to get the main ideas, understand the relationship, and make inferences (Harsiati, 2018). They are still got difficulties to engage with texts in critical manners.

Second, teachers' skills and/knowledge of critical literacy is still lack. Since students need to be engaged in higher levels of reading (Soares \& Wood, 2010) and writing, firstly, teachers as the facilitators should develop their critical literacy. Indeed, it needs a serious effort and of course, it takes time. Gustine (2018) found that even though teachers have had about seven years teaching English experience in different levels of schools, some teachers still display an absence of knowledge on critical literacy as a practical approach for English teaching. Thus, this will lead teachers to what Shor $(1999$, p. 14) called it as "not having enough authority" which refers to lack capability of the teacher to initiate a critical and 


\section{Anitha Thalib Mbau \& Bambang Sugeng}

power-sharing process. It means that teachers still need help to increase or develop their critical literacy knowledge as well as the practice in the classroom through the intensive coach.

Third, the facilities provided by schools are still inadequate. It means that schools' environment also should be supportive and responsive to students' needs responding to their needs to develop their critical literacy skills. Schools should provide sufficient facilities, any sources that can be assessed by students and contributed to the learning process such as books, magazines, newspapers, internet access, journals, movies etc. in printed and/ digital form. However, most schools in Indonesia are having lack of facilities and unavailability of materials (Adi, 2012). Therefore, the government with its literacy movement is distributing books to schools in order to support the successfulness of literacy movement itself. The books provided by the government are divided into two categories which are academic and non-academic books. In short, schools in terms of the facilities still need to provide richer sources that students can access to support their critical literacy skills.

Last, the English textbooks provided by the Government in Indonesia still need improvement in order to provide better materials to support the development of student critical literacy skills. It is because the existed textbooks do not contain many tasks which promote critical thinking (Solihati \& Hikmat, 2018). Additionally, Kasim, Zulfikar, \& Zaiturrahmi (2017) found that most of the instructional questions tend to emphasize lower order thinking skills rather than higher order thinking skills. It means that the textbooks are still limited to support students to develop students' critical manner. Ideally, to support students' critical literacy, the textbooks should also contain multiple perspectives towards an issue since they are powerful to bridge critical literacy into learning activities in the classrooms (Clarke \& Whitney, 2009). Thus, the texts should also contain some controversies issues to raise the awareness of multi-perspectives. Yet, the Ministry of Education and Culture (2016a) has regulated that the textbooks should not contain pornography, radicalism, violence, extremism, SARA, bias gender, and any inappropriate values. Consequently, the textbooks published by the government tends to be neutral which will lead to de-emphasize on critical literacy.

This short article hopefully could enlarge EFL teachers' understanding of critical literacy, particularly in Indonesia. However, since it only focuses on exploring the basic issues, it does not provide comprehensive explanations of the implementation of critical literacy in Indonesia. Further, there are still limited researches on how this new approach is implemented in the Indonesian EFL classroom. Therefore, in the future, more studies on the implementation of critical literacy are needed. It is to enrich and to contribute to the body of knowledge of critical literacy in EFL settings.

\section{CONCLUSION}

Critical literacy enables students to be active subjects rather than passive objects towards their learning processes. It is a dynamic process. It hinders students from being literate in a technical sense only. They will be involved in the four dimensions of critical literacy during their learning process including disrupting the commonplace, interrogating multiple viewpoints, focusing on sociopolitical issues, and taking actions and promoting 
social justices (Lewison et al., 2002). Therefore, the source of learning would cover not only neutral issues but also controversial issues. Consequently, teachers should choose the appropriate learning activities which could involve students to do exploration in multiple perspectives. For Indonesian context, implementing critical literacy is promising such a benefit but it is needed to give lots attention to some challenges coming from the condition of the teachers, students, facilities, and the textbooks' qualities. Finally, teachers should acknowledge the emergence of critical literacy concepts and practical issues.

\section{REFERENCES}

Adi, S. S. (2012). Communicative language teaching: Is it appropriate for Indonesian context. Instructional Technology, 51, 81-87.

Anderson, G. L., \& Irvine, P. (1993). Informing critical literacy with ethnography. In. C. Lankshear \& PL McLaren,(Eds.) Critical literacy: Politics, praxis, and the postmodern (pp. 81-104).

Beck, A. S. (2005). A place for critical literacy. Journal of Adolescent \& Adult Literacy, 48(5), 392-400.

Benesch, S. (1993). ESL, ideology, and the politics of pragmatism. TESOL Quarterly, 27(4), $705-717$.

Ciardiello, A. V. (2004). Democracy's young heroes: An instructional model of critical literacy practices. The Reading Teacher, 58(2), 138-147.

Clarke, L. W., \& Whitney, E. (2009). Walking in their shoes: Using multiple-perspectives texts as a bridge to critical literacy. The Reading Teacher, 62(6), 530-534.

Comber, B. (2001). Negotiating critical literacies. School Talk, 6(3), 1-2.

Crookes, G., \& Lehner, A. (1998). Aspects of process in an ESL critical pedagogy teacher education course. Tesol Quarterly, 32(2), 319-328.

Derewianka, B. (2003). Trends and issues in genre-based approaches. RELC Journal, 34(2), $133-154$.

Endres, B. (2001). A critical read on critical literacy: From critique to dialogue as an ideal for literacy education. Educational Theory, 51(4), 401.

Fajardo, M. F. (2015). A review of critical literacy beliefs and practices of English language learners and teachers. University of Sydney Papers in TESOL, 10.

Freebody, P. (2007). Literacy education in school: Research perspectives from the past, for the future.

Freire, P. (1972). Pedagogy of the Oppressed. New York: Herder \& Herder.

Freire, P., \& Macedo, D. (1987). Literacy: Reading the word and the world. London: Routledge.

Gainer, J. (2013). 21st-Century Mentor Texts: Developing Critical Literacies in the Information Age. Journal of Adolescent \& Adult Literacy, 57(1), 16-19.

Gee, J. P. (2008). Social Linguistics and Literacies. Routledge.

Giroux, H. (1993). Literacy and the politics of difference. Critical Literacy: Politics, Praxis, and the Postmodern, 367-377.

Gustine, G. G. (2018). A Survey on Critical Literacy as a Pedagogical Approach to Teaching English in Indonesia. Indonesian Journal of Applied Linguistics, 7(3), 531-537.

JELTL (Journal of English Language Teaching and Linguistics), 4(2), 2019 
Anitha Thalib Mbau \& Bambang Sugeng

Halliday, M. A. (1994). An Introduction to Functional Grammar, 2nd edn London. Melbourne, Auckland: Arnold.

Harsiati, T. (2018). Karakteristik Soal Literasi Membaca pada Program PISA. LITERA, 17(1).

Harste, J. C., Breau, A., Leland, C., Lewison, M., Ociepka, A., \& Vasquez, V. (2000). Supporting critical conversations. In Adventuring with books (pp. 506-554). Urbana: National Council of Teachers of English.

Huang, S. (2011). Reading "further and beyond the text": Student perspectives of critical literacy in EFL reading and writing. Journal of Adolescent \& Adult Literacy, 55(2), $145-154$.

Hyland, K. (2002). Genre: Language, context, and literacy. Annual Review of Applied Linguistics, 22(1), 113-135.

Iftanti, E. (2012). A survey of the English reading habits of EFL students in Indonesia. Teflin Journal, 23(2), 149-164.

Izadinia, M., \& Abednia, A. (2010). Dynamics of an EFL Reading Course with a Critical Literacy Orientation. Journal of Language and Literacy Education, 6(2), 51-67.

Janks, H. (2000). Domination, access, diversity and design: A synthesis for critical literacy education. Educational Review, 52(2), 175-186.

Janks, H. (2012). The Importance of Critical Literacy. English Teaching: Practice and Critique, 11(1), 150-163.

Kasim, U., Zulfikar, T., \& Zaiturrahmi, Z. (2017). Analysis of Instructional Questions in an English Textbook For Senior High Schools. English Education Journal, 8(4), 536-552.

Kern, R. (2003). Literacy as a new organizing principle for foreign language education. Reading between the Lines: Perspectives on Foreign Language Literacy, 40-59.

Kim, S. J. (2012). Critical literacy in East Asian literacy classrooms. Perspectives on Global Development and Technology, 11(1), 131-144.

Kuo, J. (2014). Critical literacy in the EFL classroom: Evolving multiple perspectives through learning tasks. The Journal of AsiaTEFL, 11(4), 109-138.

Lankshear, C., McLaren, P. L., \& McLaren, P. (1993). Critical literacy: Politics, praxis, and the postmodern. SUNY Press.

Lewison, M., Flint, A. S., \& Van Sluys, K. (2002). Taking on critical literacy: The journey of newcomers and novices. Language Arts, 79(5), 382-392.

Lock, G. (1996). Functional English grammar: An introduction for second language teachers. Cambridge: Cambridge University Press.

Luke, Alan. (2000). Critical literacy in Australia: A matter of contex and standpoint. Journal of Adolescent \& Adult Literacy, 43(5), 448-461.

Luke, Alan. (2004). Foreword. In Critical literacy: Enhancing students' comprehension of text (M. McLaughlin \& G. Devoogd, pp. 4-5). New York: Scholastic.

Luke, Allan. (2013). Regrounding critical literacy: Representation, facts and reality. In Framing languages and literacies (M. Hawkins, pp. 146-158). New York: Routledge.

Luke, Allan, \& Freebody, P. (1997). Shaping the social practices of reading. Constructing Critical Literacies: Teaching and Learning Textual Practice, 6, 460-475. 
Luke, Allan, \& Freebody, P. (1999). Further notes on the four resources model. Reading Online, 3.

McLaughlin, M., \& DeVoogd, G. (2004). Critical literacy as comprehension: Expanding reader response. Journal of Adolescent \& Adult Literacy, 48(1), 52-62.

Melrose, R. (1995). The communicative syllabus: A systemic-functional approach to language teaching. London: Pinter.

Mills, K. A. (2010). A review of the "digital turn" in the new literacy studies. Review of Educational Research, 80(2), 246-271.

Ministry of Education and Culture. (2016a). Peraturan menteri pendidikan dan kebudayaan republik Indonesia nomor 8 tahun 2016 tentang buku yang digunakan oleh satuan pendidikan.

Retrieved

from http://simpuh.kemenag.go.id/regulasi/permendikbud_08_16.pdf

Ministry of Education and Culture. (2016b). Peraturan meteri pendidikan dan kebudayaan republik Indonesia nomor 20 tahun 2016 tentang standar kompetensi lulusan pendidikan dasar dan menengah. Retrieved from http://bsnp-indonesia.org/wpcontent/uploads/2009/04/Permendikbud_Tahun2016_Nomor020.pdf

Morgan, W. (2002). Critical literacy in the classroom: The art of the possible. New York: Routledge.

OECD. (2016). Program for international student assessment (PISA) result from PISA 2015. Retrieved from https://www.oecd.org/pisa/PISA-2015-Indonesia.pdf

Oxfam. (2006). Teaching controversial issues. Retrieved from Oxfam Education website: https://www.oxfam.org.uk/education/resources/teaching-controversial-issues

Park, Y. (2011). Using news articles to build a critical literacy classroom in an EFL setting. TESOL Journal, 2(1), 24-51.

Pennycook, A. (1997). Vulgar pragmatism, critical pragmatism, and EAP. English for Specific Purposes, 16(4), 253-269.

Priyatni, E. T., \& Nurhadi. (2017). Membaca kritis dan literasi kritis. Tangerang: Tira Smart.

Republic of Indonesia. (2003). Undang-undang republik Indonesia nomor 20 tahun 2003 tentang sistem pendidikan nasional. Retrieved from https://kelembagaan.ristekdikti.go.id/wpcontent/uploads/2016/08/UU_no_20_th_2003.pdf

Rice, J. (1998). Portable critical literacy strategies. Teachers' Voices, 3, 55-60.

Shin, H., \& Crookes, G. (2005). Exploring the possibilities for EFL critical pedagogy in Korea: A two-part case study. Critical Inquiry in Language Studies: An International Journal, 2(2), 113-136.

Shor, I. (1987). Educating the educators: A Freirean approach to the crisis in teacher education. Freire for the Classroom: A Sourcebook for Liberatory Teaching, 7.

Shor, I. (1999). What is critical literacy? Journal of Pedagogy, Pluralism, and Practice, 1(4), 2.

Soares, L. B., \& Wood, K. (2010). A critical literacy perspective for teaching and learning social studies. The Reading Teacher, 63(6), 486-494. 
Anitha Thalib Mbau \& Bambang Sugeng

Solihati, N., \& Hikmat, A. (2018). Critical Thinking Tasks Manifested in Indonesian Language Textbooks for Senior Secondary Students. SAGE Open, 8(3), 2158244018802164.

Suarcaya, P., \& Prasasti, W. D. (2017). Investigating Students' Critical Reading: Critical Literacy in EFL Setting. Electronic Journal of Foreign Language Teaching, 14(2).

Vasquez, V. (2000). Our way: Using the everyday to create a critical literacy curriculum. Primary Voices K-6, 9(2), 8-13.

Yoon, B. (2015). Critical literacies: Global and multicultural perspectives. Springer.

\section{About the authors:}

Anitha Thalib MBAU is a student on English Language Education Program, Graduate School, Yogyakarta State University, Indonesia.

Bambang SUGENG is a lecture on English Language Education Programs (Undergraduate, Graduate and Post-Graduate Programs), Yogyakarta State University, Indonesia; He is currently still giving lectures after his retirement. 